\title{
Rancangan Eksperimen Analisis Struktur Mikro Sampel dengan Prinsip XRD Menggunakan Metode Kristal Berputar
}

\author{
Syaiful Rahman \\ Program Studi Pendidikan Fisika Universitas Ahmad Dahlan \\ J1. Dr. Soepomo, SH., Janturan, Warungboto, Umbulharjo, Yogyakarta, Indonesia \\ Surat-e: syaifulrahmanI05@gmail.com
}

Moh. Toifur

Magister Pendidikan Fisika Universitas Ahmad Dahlan

J1. Pramuka No. 42 Sidikan Yogyakarta

Surat-e: mtoifur@yahoo.com

Pada penelitian ini dibuat rancangan alat peraga yang secara prinsip memiliki kinerja seperti XRD yang dapat digunakan untuk menentukan jenis struktur kristal dari suatu bahan dengan perhitungan indeks bidang melalui puncak-puncak spektrum yang dihasilkan. Laser difungsikan sebagai sinar-x, sedangkan bahan sampel digunakan manik-manik dari plastik yang berbentuk bulat. Untuk memutar sampel digunakan motor stepper. Selanjutnya untuk menangkap cahaya difraksi digunakan sensor cahaya (light sensor) yang dihubungkan ke komputer. Data yang diperoleh berupa intensitas pada berbagai waktu dan diolah menggunakan microsoft excel untuk memperoleh posisi puncak dari difraksi serta indeks bidang. Hasil penelitian menunjukan bahwa rancangan alat eksperimen ini telah dapat bekerja dengan baik. Terbukti dapat menunjukkan intensitas puncak difraksi serta indeks bidangnya. Penelitian ini dapat digunakan sebagai pembelajaran fisika di perguruan tinggi, dengan produk berupa panduan praktikum fisika.

In this research, a tool performs like XRD which can be used to determine crystal structure of a material with calculation of field index through conducted spectrum have been designed. Laser functioned as the $x$-ray, meanwhile plastic beads used as sample material. To rotate the sample a motor stepper is used. Light sensor which connected to a computer used to measure the diffraction of ray. Time based intensity data measured and analyzed using Microsoft Excel to show the peak position of the diffraction and field index also. This design works well according to the result gained. This tool has proven to show the peak position of ray diffraction and field index also. The result of this research can be used as a learning tool in college, with a product of experiment guide.

Kata kunci: Difraksi sinar-X, struktur kristal, indeks bidang, Logger Pro.

\section{Pendahuluan}

XRD (X-Ray Difraction) merupakan alat untuk mengetahui indeks bidang ataupun karakteristik struktur kristal yang terdapat dari berbagai macam bahan dengan memanfaatkan hamburan sinar-X. Sinar-X terjadi apabila suatu berkas elektron bebas berenergi kinetik tinggi menumbuk logam yang merupakan sumber sinar dengan daya tembus yang besar. Kemudian elektron-elektron inilah dalam tumbukannya dengan anoda menimbulkan pancaran sinar-X, sehingga puncak-puncak akan muncul atau terlihat dari suatu bahan yang ditembakkan[I]. Dengan adanya puncak-puncak yang terbentuk dapat diketahui indeks bidang dari bahan yang digunakan.

Penggunaan dari alat ini berfungsi untuk menjelaskan materi fisika zat padat khususnya pembahasan mengenai struktur kristal dari suatu bahan. Sesuai dengan fakta yang ada, materi fisika zat padat terkait pembahasan struktur kristal pada perguruan tinggi khususnya prodi pendidikan 
fisika tergolong mata kuliah yang sulit, dikarenakan sistem pengajaran yang diajarkan atau ditekankan kepada mahasiswa hanya terfokus pada sebuah teori dan rumusan yang begitu rumit tanpa di imbangi dengan sebuah pembuktian atau eksperimen. Sehingga nantinya pemahaman maupun ketertarikan untuk mempelajari materi tersebut akan sedikit berkurang dan takutnya mahasiswa akan merasa jenuh, suntuk, dan bosan. Padahal sejatinya fisika itu adalah ilmu yang didasarkan pada pengamatan-pengamatan eksperimen[2]. Artinya, mahasiswa melakukan pembuktian dengan cara percobaan eksperimen tentang kebenaran teori yang diajarkan dan hasil dari percobaan tersebut dibandingkan dengan teori yang sudah ada. Apakah nantinya hasil percobaan tersebut sesuai apa tidak dengan teori yang sebenarnya.

Namun keberadaan alat XRD ini di laboratorium khususnya prodi pendidikan fisika belum ada, dikarenakan harga alat tersebut terbilang cukup mahal. Maka, perlu adanya alternatif lain atau solusi untuk menggantikannya baik dari segi harga yang terjangkau ekonomis. Dari situ saya mencoba untuk membuat atau merancang sebuah alat peraga yang secara prinsip telah memenuhi seperti XRD, dapat digunakan untuk menentukan jenis struktur kristal dari suatu bahan dengan perhitungan indeks bidang melalui puncak-puncak spektrum yang dihasilkan. Alat peraga ini berbeda dengan yang aslinya dilihat dari tampilan bentuk fisik lebih kecil agar terlihat sederhana dan juga dari segi harga. Dengan adanya alat tersebut mahasiswa bisa melakukan sendiri ekpserimen untuk membuktikan kebenaran teori serta bisa lebih memahami materi yang diajarkan. Selain jika eksperimen berhasil maka dapat dibuat modul praktikum untuk kegiatan belajar mengajar dalam materi struktur kristal pada mata kuliah fisika zat padat.

\section{Kajian Pustaka}

\section{X-Ray Difraction (XRD)}

XRD merupakan suatu teknik pengujian yang digunakan untuk menentukan unsur dan senyawa kimia, struktur kristal, parameter kisi, volume, kisi dan lainlain[3]. Sedangkan menurut [4] mengatakan bahwa Difraksi sinar-X merupakan teknik yang digunakan untuk menganalisis padatan kristalin.

\section{Metode difraksi sinar-X}

Seberkas Sinar-X dipantulkan dari sehimpunan bidang kristal yang berjarak antara $d$ berkas sinar yang dipantulkan dari bidang yang kedua menempuh jarak $2 d \sin \theta$ lebih panjang dari pada berkas yang dipantulkan dari bidang pertama, dengan adalah sudut datang yang diukur terhadap permukaan kristal.
Sinar-sinar pantul yang sefase berbeda lintasan sebesar kelipatan bulat dari panjang gelombang akan menimbulkan interferensi saling menguatkan. Pemantulan dan interferensi bergabung menjadi difraksi. Difraksi akan saling menguatkan jika terpenuhi persamaan Bragg sebagai berikut

$$
2 d \sin \theta=n \lambda
$$

Hasil tersebut dikenal dengan sebagai hukum Bragg bagi difraksi Sinar-X. Dengan $d$ merupakan jarak antara bidang (hkl) untuk sebuah kristal, $\theta$ adalah sudut Bragg, $\lambda$ adalah panjang gelombang radiasi, dan bilangan bulat $n$ $=\mathrm{I}, 2,3$, dan seterusnya $[5]$.

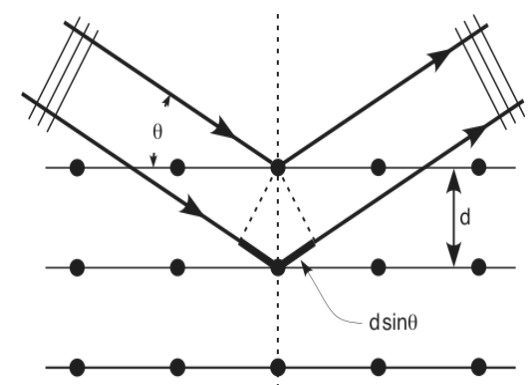

Gambar I. Hamburan Sinar-X pada kristal.

Berdasarkan penetapan salah satu dari parameter tersebut metode difraksi dapat dibagi menjadi tiga jenis yaitu: I) Metode Laue, 2) Metode kristal berputar, 3) Metode serbuk.

\section{Metode Laue}

Metode difraksi ini tidak menggunakan sinar monokromatik dan spektrumnya juga tidak menggunakan karakteristik melainkan menggunakan yang kontinu dari logam targetnya[3]. Eksperimen metode Laue menggunakan sinar-X polikromatis dengan arah tetap. Metode Laue dapat digunakan untuk menentukan orientasi bidang kristal tunggal[5].

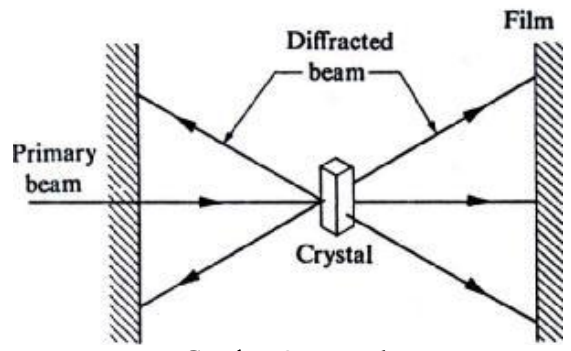

Gambar 2. Metode Laue.

\section{Metode kristal berputar}

Pada umumnya metode ini digunakan untuk menganalisa struktur kristal tunggal. Metode ini menggunakan sinar-X monokromatis dengan sudut datang divariasi[5]. Proses metode kristal berputar ini 
terjadi ketika kristal dari sampel uji disinari oleh sinar-X dan sinar-X tersebut mengelilingi kristal sehingga pada orientasi tertentu akan dihasilkan berkas difraksi [3].

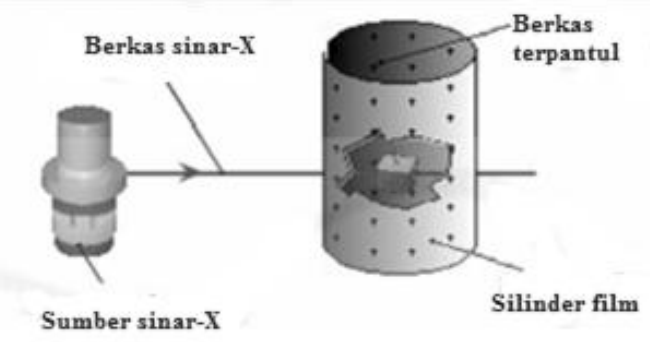

Gambar 3. Metode rotasi kristal.

\section{Metode serbuk}

Dalam metode serbuk ini kristal yang akan diamati dalam bentuk serbukan dengan setiap butir serbuk berlaku sebagai kristal berukuran kecil, dengan orientasi acak dan diputar tidak melalui satu sumbu saja. Alternatif lain adalah menggunakan difraktometer sebagai pengganti kamera dan hasil difraksi direkam dalam chart recorder $[3]$.

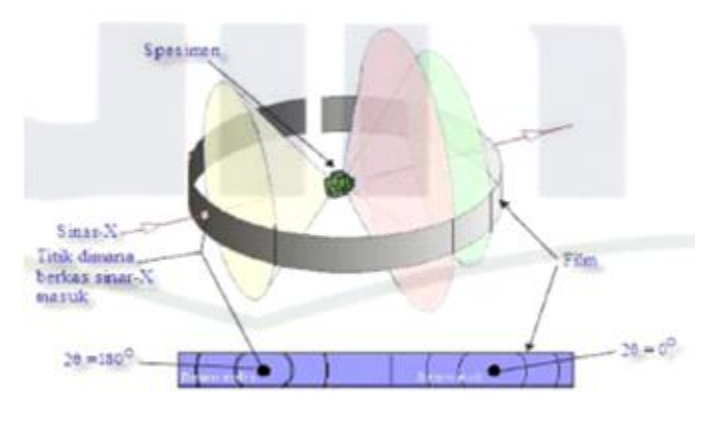

Gambar 4. Metode serbuk.

\section{Penentuan indeks Miller pada kristal kubus}

Penentuan indeks bidang pada kristal kubus dapat dicari dengan menggunakan hukum Bragg sebagai berikut: Misalkan untuk $n=\mathrm{I}$, maka persamaan Bragg adalah :

$$
\begin{aligned}
& 2 d \sin \theta=n \lambda \\
& 2 d \sin \theta=\lambda \\
& \sin \theta=\frac{\lambda}{2 d}
\end{aligned}
$$

Dari persamaan (I) jika disubsitusikan ke persamaan (2) maka diperoleh:

$$
\sin \theta=\frac{\lambda\left(h^{2}+k^{2}+l^{2}\right)^{\frac{1}{2}}}{2 a}
$$

Jika persamaan (3) dikuadratkan, maka persamaan (3) menjadi:

$$
\begin{aligned}
& \sin ^{2} \theta=\frac{\lambda\left(h^{2}+k^{2}+l^{2}\right)}{4 a^{2}} \\
& \sin ^{2} \theta=\left(\frac{\lambda^{2}}{4 a^{2}}\right)\left(h^{2}+k^{2}+l^{2}\right)
\end{aligned}
$$

Dengan memisalkan $\left(\frac{\lambda}{2 d}\right)^{2}=A$ (faktor umum), sehingga rumusannya menjadi:

$$
\sin ^{2} \theta=A\left(h^{2}+k^{2}+l^{2}\right)
$$

Untuk 2 sudut puncak difraksi, misalnya $\theta_{2}$ dan $\boldsymbol{\theta}_{1}$ maka berlaku:

$$
\sin ^{2} \theta_{2}=A\left(h_{2}{ }^{2}+k_{2}{ }^{2}+l_{2}{ }^{2}\right)
$$

dan

$$
\sin ^{2} \theta_{1}=A\left(h_{1}{ }^{2}+k_{1}{ }^{2}+l_{1}^{2}\right)
$$

Jika persamaan (6) dibagi dengan persamaan (7) maka diperoleh:

$$
\frac{\sin ^{2} \theta_{2}}{\sin ^{2} \theta_{1}}=\frac{h_{2}^{2}+k_{2}^{2}+l_{2}^{2}}{h_{1}^{2}+k_{1}^{2}+l_{1}^{2}}
$$

Dengan rumusan di atas, maka dapat diketahui indeks bidang kristal suatu bahan. Kemudian dari data pola difraksi yang dihasilkan, ditentukan terlebih dahulu posisi sudut hamburan Bragg $(2 \theta)$, dan ditentukan juga sudut $\theta$. Selanjutnya dihitung dari masing-masing puncak yang dihasilkan. Harga $\left(h^{2}+k^{2}+l^{2}\right)$ untuk sistem ini tergantung dari kristal kubus yang digunakan. Apakah kubus sederhana, kubus pusat badan, dan kubus pusat muka (lebih jelasnya lihat nilai dari masing-masing kristal kubus). Setelah nilai (hkl) untuk kristal kubus ditentukan, selanjutnya harga $\sin ^{2} \theta_{2} / \sin ^{2} \theta_{1}$ atau dapat dinyatakan dengan $\sin ^{2} \theta$ dibagi dengan $\sin ^{2} \theta_{\min }$. Kemudian hasil pembagian dari $\sin ^{2} \theta$ dibagi dengan $\sin ^{2} \theta_{\min }$ dikali bilangan pertama dari aturan seleksi kisi bravais untuk kristal kubus harus mendekati bilangan bulat (tergantung nilai (hkl) dari sistem kristal kubus yang digunakan), maka nilai indeks bidang (hkl) dari sistem kubus dapat ditentukan.

\section{Metode Penelitian/Eksperimen}

Menentukan grafik puncak-puncak spektrum yang dihasilkan oleh sudut putaran 
Metode analisis data yang digunakan dalam penelitian ini adalah dengan menggunakan analisis loggerpro dan microsoft excel, yaitu dengan membuat grafik ketika sinar laser mengenai suatu bahan terhadap sudut putaran dari motor stepper, maka akan terlihat grafik intensitas yang dihasilkan pada layar logger pro. Kemudian dilakukan perhitungan puncak-puncak spektrum menggunakan persamaan sebagai berikut, untuk 2 sudut puncak difraksi pada struktur kristal kubus:

$$
\frac{\sin ^{2} \theta_{2}}{\sin ^{2} \theta_{1}}=\frac{h_{2}{ }^{2}+k_{2}{ }^{2}+l_{2}{ }^{2}}{h_{1}{ }^{2}+k_{1}{ }^{2}+l_{1}{ }^{2}} \text { atau } \frac{\sin ^{2} \theta_{1}}{\sin ^{2} \theta_{\text {min }}}
$$

\section{Alat dan Bahan}

Alat dan bahan yang digunakan pada penelitian ini adalah: (I) sumber sinar-X digunakan laser, sebagai bahan digunakan manik-manik dari plastik, dan sebagai pemutar sampel digunakan motor stepper. Untuk menangkap cahaya difraksi digunakan sensor cahaya (light sensor) yang dihubungkan dengan interface labquest dan ditampilkan pada layar komputer dengan bantuan software Logger Pro. Interface adalah sebagai penghubung dengan light sensor. Interface yang digunakan adalah LabQuest Mini dari Vernier. Light Sensor adalah sensor cahaya digunakan sebagai pengganti detektor untuk menangkap cahaya difraksi serta ditampilkan di komputer dan mudah untuk dianalisis. Laptop digunakan untuk menampilkan data yang dibaca oleh sensor. Logger Pro yang digunakan pada penelitian ini adalah Logger Pro 3.8.4. (2) sedangkan bahan yang digunakan berupa manik-manik dari plastik, dimana manik-manik dari plastik ini dianggap sebagai sebuah atom-atom. Desain penelitian seperti terlihat pada gambar 5 sebagai berikut.

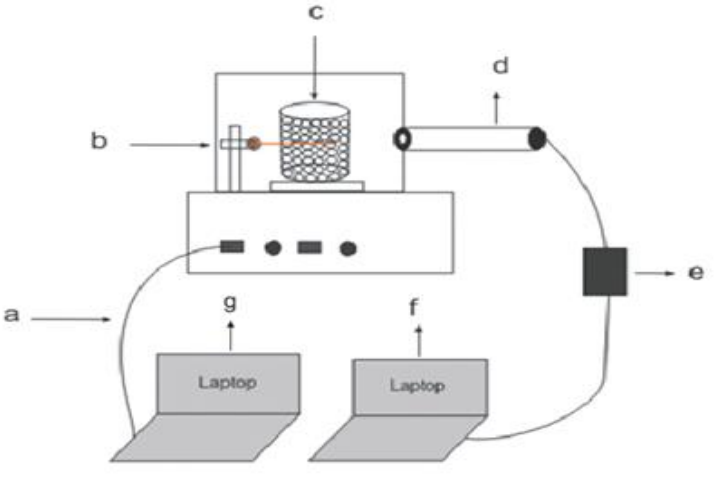

Gambar 5. Desain alat penelitian.

\section{Keterangan:}

a. Kabel penghubung (USB).

b. Sinar laser.

c. Manik-manik plastik.

d. Sensor cahaya. f. Interface.

g. Laptop I(untuk menjalankan Logger Pro).

h. Laptop 2 (untuk menjalankan motor stepper).

\section{Hasil Penelitian dan Pembahasan}

Sudut putaran $180^{\circ}$ diperoleh data grafik dalam tampilan logger pro sebagai berikut.

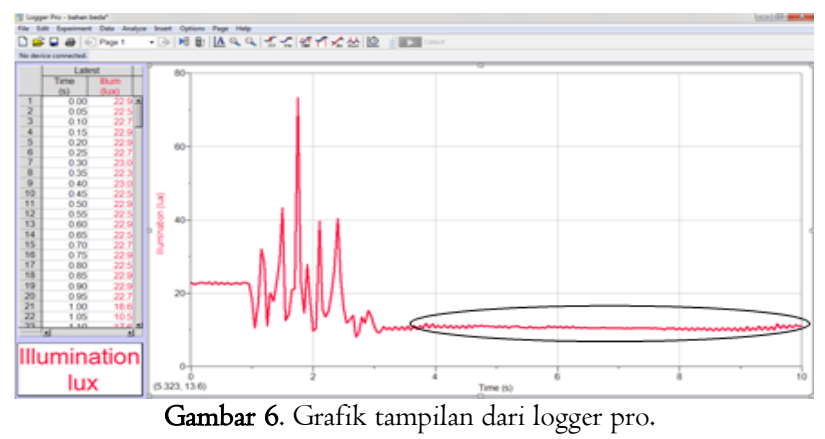

Grafik di atas merupakan difraksi atau pemantulan yang dihasilkan oleh material yang digunakan yaitu bahan plastik. kemudian dapat diuraikan intensitas cahaya dari sudut putaran yang diberikan menggunakan microsoft excel. Sedangkan untuk garis lurus panjang yang ditunjukkan oleh lingkaran hitam menunjukkan bahwa sinar yang mengenai bahan pada saat putaran merupakan bahan amorfus, artinya difraksi atau pantulan dari sinar tersebut tidak terbaca sensor cahaya. Dikarenakan Selanjutnya, analisis puncak difraksi menggunakan microsoft excel. Kemudian kita menggantikan time pada logger pro menjadi sudut 2Theta pada microsoft excel.

Sehingga grafik intensitas cahaya yang dihasilkan, terdapat puncak-puncak yang terbentuk. Dari puncakpuncak yang terbentuk dapat diketahui indeks bidang dari suatu bahan yang digunakan dengan menggunakan persamaan (9) dan menganggap bahan material tersebut termasuk dalam kristal kubus pusat muka, sehingga terlihat seperti pada gambar 7 dan hasil perhitungan indeks bidang dengan menggunakan aturan kristal kubus pusat muka dapat dilihat pada tebe I.

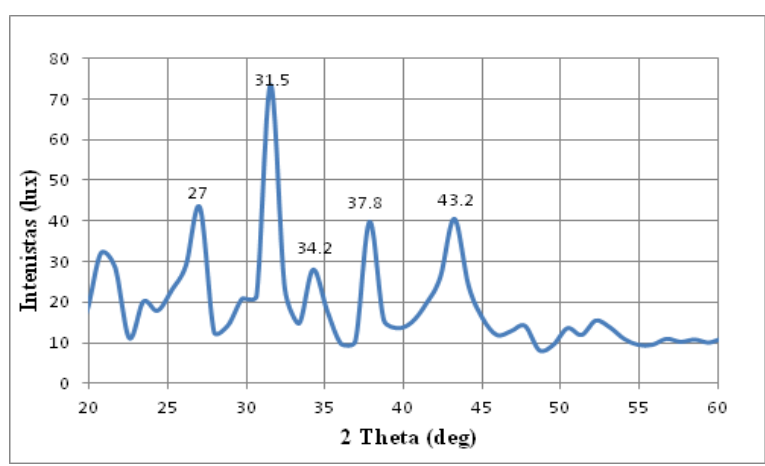

Gambar 7. Grafik hubungan intensitas cahaya terhadap sudut. 
Tabel I. Data hasil perhitungan puncak-puncak yang terbentuk.

\begin{tabular}{|c|c|c|c|c|c|c|}
\hline $\begin{array}{l}\text { Puncak } \\
\text { ke }\end{array}$ & $\begin{array}{l}\text { Sudut } \\
2 \theta\end{array}$ & $\begin{array}{l}\text { Sudut } \\
\theta\end{array}$ & $\sin ^{2} \theta_{2} / \sin ^{2} \theta_{1}$ & $\left(\sin ^{2} \theta_{2} / \sin ^{2} \theta_{1}\right) \times 3$ & $h^{2}+k^{2}+l^{2}$ & $\begin{array}{l}\text { Indeks } \\
\text { bidang } \\
(h k l)\end{array}$ \\
\hline 1 & 27 & 13,5 & 1,00 & 3,00 & 3 & {$[111]$} \\
\hline 2 & 31,5 & 15,75 & 1,35 & 4,06 & 4 & {$[200]$} \\
\hline 3 & 34,2 & 17,1 & 1,59 & 4,76 & 5 & {$[210]$} \\
\hline 4 & 37,8 & 18,9 & 1,93 & 5,78 & 6 & {$[211]$} \\
\hline 5 & 43,2 & 21,6 & 2,49 & 7,47 & 8 & {$[220]$} \\
\hline
\end{tabular}

Dari hasil yang diperoleh pada tabel tersebut, dapat diketahui puncak-puncak atau indeks bidang dari struktur kubus seperti pada sudut 2Theta $27^{\circ}$ memiliki indeks bidang sebesar [III], sudut 2 Theta $31,5^{\circ}$ memiliki indeks bidang sebesar [200], sudut 2Theta $34,2^{\circ}$ memiliki indeks bidang sebesar [210], dan seterusnya.

\section{Kesimpulan}

Berdasarkan hasil penelitian yang telah dilakukan diketahui bahwa alat bekerja dengan baik dan dapat digunakan untuk praktikum, terbukti alat dapat menentukan struktur kristal dari suatu bahan dengan mengetahui indeks bidangnya.

\section{Kepustakaan}

[I] Y. Wiyatmo, Fisika Modern, Yogyakarta: Pustaka Pelajar, 2002.

[2] R. A. Serway, dan J. W. Jewett, Physics for Scientists and Engineers with Modern Physics. Alih Bahasa Chriswan Sungkono Fisika untuk Sains dan Teknik Buku 3 Edisi 6, Jakarta: Salemba Teknika, 2010

[3] A. Krisnawan, Karakterisasi Sampel Paduan Magnesium Jenis AZ9 ID dengan Berbagai Variasi Waktu Milling menggunakan XRF dan XRD. Skripsi, Universitas Islam Negeri Syarif Hidayatullah, Jakarta, 2009

[4] R. Rusli, Difraksi Sinar-X, 201 I. website:

http://rolanrusli.com/difraksi-sinar-x/Doc, diakses pada tanggal 5 Oktober 2015 pukul 08.50.

[5] S. Wijayanti, Analisa Pola-Pola Difraksi Sinar-X Pada Material Serbuk Nd6FeI3Sn, Nd6FeI3Ge dan Nd6FeI3Si Menggunakan Metode Rietveld GSAS, Skripsi, Universitas Sebelas Maret, Surakarta, 2007. 